Author: D L Carey Miller

PUBLIC ACCESS TO PRIVATE LAND IN SCOTLAND

ISSN 1727-3781

2012 VOLUME 15 No 2

http://dx.doi.org/10.4314/pelj.v15i2.6 


\section{PUBLIC ACCESS TO PRIVATE LAND IN SCOTLAND}

D L Carey Miller*

Introduction

This paper is concerned with a radical reform of Scottish land law introduced as part of the initial agenda of the Scottish Parliament reconvened in Edinburgh in 1999 after some 300 years. The reform concerned provides for rights of public access to private land. ${ }^{1}$ Access to land is of fundamental significance concerning issues of land governance, the theme of a conference ${ }^{2}$ at which a first version of the paper was given. The tension between private rights and the interests of the public may be seen to have a particular focus in the issue of public access to private land. The primary aim of this account will be to identify the scope of the new Scottish right in an attempt to determine the true nature of the change and, in particular, its significance as a limitation of the right of property.

The essential focus of the paper is on the "access rights" provided for in part 1 of the Land Reform (Scotland) Act 2003, which came into force on 9 February 2005. ${ }^{3}$ The paper will cover the subject under the following headings: the pre-reform position; the essential features of the reform; excluded land; the Scottish Outdoor Access Code; the European Convention on Human Rights; the English law approach; and concluding observations.

My Aberdeen colleague, Professor Roddy Paisley, commissioned by the Scottish Rights of Way and Access Society (Scotways), has written a revised edition of Professor A E Anton's guide to Scottish access rights and rights of way to take

* David L Carey Miller. Emeritus Professor of Property Law, University of Aberdeen, Senior Associate Research Fellow, Institute of Advanced Legal Studies, London, Advocate of the High Court of South Africa. My Aberdeen colleague Malcolm Combe most kindly read and commented in a full and valuable way on a draft, but the errors and failings in this final version are mine alone.

1 The Land Reform (Scotland) Act 2003, Part 1, brought into force on 9 February 2005 (SSI 2005 No 17).

2 "Good Governance in Land Tenure" supported by the Konrad Adeneauer Stuftung; organised by Professor Gerrit Pienaar and held at the Potchefstroom Campus of the University of North-West, South Africa, 22/23 April 2010.

3 For an important general comment on the reforms in context, see Sellar 2006 Norwegian Journal of Geography. 
account of the 2003 access reforms. ${ }^{4}$ This work is invaluable in putting the farreaching statutory access reforms into the context of the relevant common law. ${ }^{5}$

Since I wrote the conference version of this paper, Professor John A Lovett of Loyola, New Orleans, USA has published a very full and most valuable study of Scottish access following a research visit to Edinburgh University as a Neil MacCormack Visiting Scholar in 2009. ${ }^{6}$ That study is referred to a number of times in this revised version of my paper.

\section{The pre-reform position}

There is no delict of trespass in the Romanist common law of Scotland; the landowner has an enforceable right to require a trespasser to leave but there is no civil claim for the act of trespass per se as there is, on the basis of the "tort of trespass", in English law. ${ }^{7}$ T B Smith (later Professor Sir Thomas), considering the scope of land ownership in his noted textbook, ${ }^{8}$ quoted the first Lord President Clyde's dictum ${ }^{9}$ that the word "trespasser" in Scotland is a popular rather than a legal term. The point here is that the civilian-based law of delict of Scots law does not recognise a right to damages arising from the act of trespass itself; trespass to land is only potentially relevant as a basis for liability where it has resulted in damage, ${ }^{10}$ this being remedied by an action directed to reparation for patrimonial loss derived from the Roman Lex Aquilia. ${ }^{11}$ The point, noted by Professor Kenneth Norrie in a recent authoritative work, is that it is "not damages for the trespass, but damages for the hurt to the property". ${ }^{12}$

4 See Paisley Access Rights.

5 Another valuable study is that of Tom Guthrie of the Law School of the University of Glasgow; see Guthrie "Access Rights" 125.

6 Lovett $2010 \mathrm{Neb}$ L Rev.

7 See below $\mathrm{n} 19$.

8 Smith Short Commentary 526.

9 Dumbreck v Addie 1928 SC 547, 554

10 See Reid Law of Property para 185. See also Lovett 2010 Neb L Rev 762: "trespass in Scotland is primarily viewed as constituting a tort...assuming there is damage".

11 Smith British Justice 158.

12 Norrie "Intentional Delicts" 508. 
As stated, however, a landowner can exclude one who has no right to be present on land and the remedy of interdict is potentially applicable to repeated incursions. ${ }^{13}$ Even the right to apply self-help to the removal of an unwanted "trespasser" is, according to certain authorities, a circumscribed one. ${ }^{14}$ Relevant legislation, ${ }^{15}$ concerned only with possible criminal purpose, appears to reflect the common law position that the mere fact of presence on the land of another is not, in itself, a wrong in the eyes of the law. ${ }^{16}$

Accordingly, on this basis, while it is correct to say that in Scotland there is no "delict of trespass", ${ }^{17}$ it is "loose and inaccurate"18 to say that there is no "law of trespass". This legal distinction is sometimes misunderstood, or even denied, as in a work urging the opening up of "Britain's countryside" by a "right to roam". ${ }^{19}$

By tradition Scottish landowners are tolerant of hill walkers (or hikers) and have tended to allow a precarious freedom of access to the hills and mountains. This position is the basis of a preface statement in Professor Paisley's recent edition of the access guide by George Menzies (chairperson of Scotways) that "Scotland has a great heritage of access to the countryside". ${ }^{20}$ The rich history of hill walking and the associated "Munro bagging" would never have come to pass without landowners being tolerant of responsible access by the public. ${ }^{21} \mathrm{~A}$ mid-nineteenth century obiter

13 Reid Law of Property para 183.

14 Reid Law of Property para 184: "A bare trespass on land...does not always justify the use of force".

15 Wildlife and Natural Environment (Scotland) Act 2011 (which will supersede the Night Poaching Acts 1828 and 1844, Trespass (Scotland) Act 1865 and Criminal Justice and Public Order Act 1944)

16 The predominant feature of the pre-existing position is a "lack of clarity": see Guthrie "Access Rights" 127.

17 Or "tort of trespass" in the terminology of English law.

18 Paisley Access Rights 40 quoting Lord Trayner in Wood v North British Railway 1899 2F 1, 2.

19 Shoard Right to Roam 13: "There is a mysteriously widespread belief that Scotland has no law of trespass or that Scottish trespass law is in some way fundamentally different from English law. It is not". On the following page (14) the author says that "[d]amages for trespass where no actual loss has been incurred are not however available even in theory in Scotland". This later statement reflects the very point which represents a significant legal difference.

20 Paisley Access Rights 5. See also relevant comments in Carey Miller and Combe 2006 www.ejcl.org 22.

21 One need only peruse the annals of the Cairngorm Club, established in Aberdeen in 1887, to appreciate the longstanding popularity of Scottish hillwalking and mountaineering; see the Cairngorm Club Journal first published 1896, most recently 2007 (vol 21, no 108); see, generally Cairngorm Club [Date unknown] www.cairngormclub.org.uk. 
dictum of Lord Deas ${ }^{22}$ describes the situation of a technically precarious position that was, in practice, essentially secure.

In regard to going to the top of the hill and down again, it would have been an unreasonable thing to stop people going in the then state of matters. I have been familiar with hills myself, on which I would have thought it a most invidious thing if I had been prevented from going to the top and down again, and I never knew of anybody being so prevented. But that did not give a right, and could not be pretended to have been done in the exercise of a right.

A general right of public access to all land was on the agenda of the Scottish Labour administration when parliament - in devolved form - returned to Edinburgh. Early in the new Parliament a Land Reform Bill was published; its provisions included a right of access package.

A National Access Forum, established by Scottish National Heritage in 1994, had brought together the main national interest groups to consider access issues at a national level. The Forum's work led to advice to the Scottish Government concluding that the prevailing uncertainty was unsatisfactory for both landowner and access seeker, ${ }^{23}$ a position supported by academic advocates of reform. ${ }^{24}$ As John Lovett ${ }^{25}$ observes "no one was particularly happy with the status quo in Scotland".

An accurate view of the pre-reform status quo should not deny that general social practice in Scotland allowed substantial access to the countryside for recreational purposes - if not the definite general right of the reformed law. The reforms have substituted a new unitary controlling responsible right structure for the previous position in which the strict legal position was in favour of the landowner but, in practice, access to hills and mountains was widely available and participated in by large numbers of walkers and climbers.

22 Jenkins v Murray 1866 4M 1046, 1054.

23 Scottish National Heritage Access to the Countryside; on the history of the development, see National Access Forum [Date unknown] www.outdooraccess-scotland.com.

24 See Rowan-Robertson and Ross 1998 Edin L R 225.

25 Lovett $2010 \mathrm{Neb} L \operatorname{Rev} 766$. 


\section{The essential features of the reform}

The Act provides, first, a right of access to all land and inland waterways for recreational or educational purposes and for any commercial purposes involving an activity that is not inherently profit driven ${ }^{26}$ (e.g. access by a paid walking tour guide) and, secondly, the "right to cross land". ${ }^{27}$ The scope of the two distinct spheres of the right - respectively, access for recreational, educational or certain commercial purposes, and for crossing (i.e. passage) - are clarified by the provisions of the legislation. The recreational, educational or potentially commercial aspect is stated to refer to "going into, passing over and remaining on it [i.e. the land] for any of those purposes and then leaving it, or any combination of those". ${ }^{28}$ The crossing aspect refers to "going into it, passing over it and leaving it all for the purpose of getting from one place outside the land to another such place". ${ }^{29}$

Importantly, the right in both its aspects is subject to a general exclusion and a limited category of particular exclusions. The general one of responsible exercise is integral to the definition of the scope of the right in that it applies in every instance of the right's availability. This important limitation of the right and its correlative - the landowner's obligation - will be considered before looking at the (obviously different in kind) specific "context of application" limits. By reason of its generality the responsible conduct limit is the most significant qualification of the right. But certain specific conduct limits are also relevant to the quite complex definition of the right. These will be noted in the following section after comment on the generic responsible conduct qualification. The exclusion of certain categories of land is another aspect of the scope of the right but, being distinct from the limits concerned with conduct, this issue will be dealt with in a separate section.

An important feature of the legislation is a significant local authority function in respect of the facilitation and upholding of access rights. This is provided for in Chapter 5 of the Act. ${ }^{30}$ Certain particular provisions from that part will be mentioned

26 Sections 1(2)(a) and 1(3)(a), (b) and (c) Land Reform (Scotland) Act 2003.

27 Section 1(2)(b) Land Reform (Scotland) Act 2003.

28 Section 1(4)(a)(i) and (ii) Land Reform (Scotland) Act 2003.

29 Section 1(4)(b) Land Reform (Scotland) Act 2003.

30 Sections 13-27 Land Reform (Scotland) Act 2003. 
in the context of the present treatment but it is beyond the scope of this paper to consider the local authority function aspect in any comprehensive way.

\subsection{The prerequisite condition of responsible exercise}

In providing that "[a] person has access rights only if they are exercised responsibly" ${ }^{31}$ the wording of the Act gives the condition prerequisite status. This is clearly important with regard to the extent to which the legislation is an inroad into the right of ownership because, provided a landowner co-operates with the spirit and system of the Act in terms of the reciprocal obligation, it will be open to him or her to deny access on the basis that it is not being exercised responsibly. But the onus is on the landowner to show that the exercise is not responsible. This is apparent in the wording of the Act, that "[i]n determining whether access rights are exercised responsibly" the exercise is presumed to be responsible if it does not "cause unreasonable interference with any of the rights (whether access rights, rights associated with the ownership of land or any others) of any other person". ${ }^{32}$

The significance of the "responsible exercise" qualification of the right was recognised in the only Court of Session decision thus far on the statutory right of access. ${ }^{33}$ This decision of an Extra Division of the Inner House (Lords Eassie, Hardie and Mackay of Drumadoon) was an appeal from the Dingwall Sheriff Court. ${ }^{34}$ The focus of the matter was the issue of a landowner's reciprocal obligation to use and manage the land concerned in a responsible manner but, of course, the court needed to clarify the position of the legislative context which defines the right of access itself. The opinion of the Court, delivered by Lord Eassie, sets out the provisions of section 2 providing for responsible exercise, section 3 regarding a landowner's reciprocal obligations and section 14 prohibiting deterrent signs or obstructions as the relevant legislative framework. This important comment follows:

31 Section 2(1) Land Reform (Scotland) Act 2003.

32 Section 2(2) Land Reform (Scotland) Act 2003.

33 Graham and Margo Tuley v Highland Council 2009 SLT 616. For an analysis of the decision see Combe 2010 Edin L R 106, 107-109.

34 Highland Council v Graham and Margo Tuley 2007 SLT (Sh Ct) 77. 
It is evident from these provisions - and appeared to be recognised by counsel on both sides - that the notion of acting "responsibly" plays an important part in the scheme of the legislation. Thus a person taking access to land has no right of access if he is not acting "responsibly" (section 2(1)). An attempt to add some precision to the broad concept of "responsible exercise" is to be found in section 2(3). The access-taker is also presumed, subject to certain qualifications, to be exercising access rights responsibly if those rights are exercised so as not to cause unreasonable interference with the rights of any other person (section 2(2)). ${ }^{35}$

This authoritative interpretation of the core "responsible exercise" criterion is significant in confirming that having access rights "only if they are exercised responsibly" means that the right is denied to a taker not acting responsibly. Presenting the proposition in the negative is an acknowledgement of the inherent position of a circumscribed right.

The issue as to whether or not access rights are disallowed because of unreasonable interference with another's existing rights is potentially controversial but, as indicated, the Act clarifies matters to the extent of the specific exclusion of access rights in a mixed category of situations. In these particular circumstances the issue of responsible exercise does not arise because access is disallowed. Section 9 lists the situations under the heading "[c]onduct excluded from access rights" as: (a) where presence is in breach of an interdict or other judicial order; (b) where presence is for a criminal purpose or a purpose in breach of an interdict or other judicial order; (c) for hunting, shooting or fishing; (d) while responsible for a dog or other animal not under proper control; ${ }^{36}$ (e) where presence is for the removal, for commercial purposes or profit, of anything in or on the land; (f) using a motorised vehicle or vessel other than one for and used by a disabled person; ( $g$ ) being on a golf course for the recreational, educational or a permitted commercial purpose provided for (but, significantly, without implications for the right to cross a golf course). ${ }^{37}$

35 Graham and Margo Tuley v Highland Council 2009 SLT 616 para 17.

36 On this see Reid and Gretton Conveyancing 138-139.

37 Reading ss 6(1)(e), 7(b) and 9(g) together, it would appear that the access right over a golf course is limited to crossing, provided this does not involve traversing a green. The Code para 2.2 of the Access Code (see below section 5) refers to golf as open to access "but only for crossing them and providing that you do not take access across greens or interfere with any games of golf". Rather surprisingly the Code (in the Part 5 Practical Guide) envisages the possibility of cyclists and horse riders on golf courses but they "need to keep to paths at all times and not go on to any other part of the course". 
What is the position of a landowner who considers that the access right is not being exercised in a responsible way? In the event of the statutory access right being disallowed through irresponsible exercise ${ }^{38}$ the affected landowner's common law rights apply. In principle, in this situation, the use of reasonable means to obtain the removal of the person or persons concerned should be open to the landowner. This interpretation seems to be supported by a definitional provision that "[t]he exercise of access rights does not of itself constitute trespass". 39 There being no access right if exercise is not responsible, it follows that access of this sort does constitute trespass open to the remedy of removal.

A recent dictum of Sheriff Holligan recognises the significance of the "responsible exercise" qualification in terms of the availability of the access right. Elaborating on the comment that "it is important to note that a person only has such rights if they are 'exercised responsibly'" the learned Sheriff went on to comment:

\begin{abstract}
Accordingly, in my opinion, by prescribing that a person has access rights only if exercised responsibly, it follows that should a person purport to exercise the rights in a way which is irresponsible, such a person is no longer exercising access rights conferred by the 2003 Act and is therefore no longer entitled to such protection as the 2003 Act confers upon someone who does exercise the rights responsibly. ${ }^{40}$
\end{abstract}

It is submitted that this dictum is consistent with the Court of Session one in Tuley quoted above. ${ }^{41}$

A possible example of irresponsible behaviour would be an access taker's refusing to take an alternative route when requested to do so because crop spraying is affecting the safety of using the preferred route. ${ }^{42}$ Proceeding in these circumstances would not be responsible and the right would be disallowed with the consequence that the landowner's common law right to require and, if necessary, enforce removal would be restored.

38 Section 2(1) Land Reform (Scotland) Act 2003.

39 Section 5(1) Land Reform (Scotland) Act 2003.

40 Forbes $v$ The Fife Council 2009 SLT (Sh Ct) 71 para 23.

41 Graham and Margo Tuley v Highland Council 2009 SLT 616 para 17.

42 See Access Code 5.1, discussed below in section 5: "Fields where crops are being sprayed or fertilised". 


\subsection{A landowner's reciprocal obligation}

As indicated, the Act introduced a regime in which the primary right is a prescribed entitlement to responsibly exercised access to another's land. The right necessarily involves a correlative obligation to accede to responsibly exercised access within the prescribed limits, but the Act goes further in a section providing for the "reciprocal obligations of owners". ${ }^{43}$ This section imposes a duty on "every owner of land in respect of which access rights are exercisable - (a) to use and manage the land; and (b) otherwise to conduct the ownership of it, in a way which, as respects those rights, is responsible". ${ }^{44}$ The section's reference to "responsible" is stated to refer to what "is lawful and reasonable and takes proper account of the interests of persons exercising or seeking to exercise access rights". 45

A landowner's exercise of inherent rights is deemed to be responsible "if it does not cause unreasonable interference with the access rights of any person exercising or seeking to exercise" his or her rights under the Act. However, two matters are specified as relevant to recognition of the presumption. Firstly, conduct in contravention of the prohibition of signs, obstructions and dangerous impediments under section 14 is to be taken as not meeting the responsible conduct criterion; ${ }^{46}$ secondly, regard should be had to anything done by the landowner in disregard of the guidance on responsible conduct in the Access Code. ${ }^{47}$

The Court of Session decision Tuley v Highland Counci ${ }^{48}$ already referred to is relevant to the reciprocal obligation of an owner. The issue in this case was not a question of a landowner's privacy but rather one of power and control over decisions concerning the provision of recreational access. Essentially, the issue was whether or not the landowners could 'manage' the situation by erecting a barrier to prevent

43 Section 3 Land Reform (Scotland) Act 2003.

44 Section 3(1) Land Reform (Scotland) Act 2003.

45 Section 3(3) Land Reform (Scotland) Act 2003.

46 Section 3(2)(a) Land Reform (Scotland) Act 2003.

47 Section 3(2)(b) Land Reform (Scotland) Act 2003. Part 5 of the Access Code provides "a practical guide to access rights and responsibilities" listing 48 situations or activities concerning responsible behaviour by the public and land managers. The Code (5.1) states that the coverage is not complete "but it should help to indicate what is or is not responsible behaviour". The legal status of the code is discussed below.

48 Graham and Margo Tuley v Highland Council 2009 SLT 616. 
equestrian use of a path as a protection against erosion which might make it unsuitable for walkers. It was argued that even though damage was likely to occur, horse riders had rights of access which they were entitled to exercise over suitable tracks and, on this basis, it was premature and irresponsible to close routes in anticipation of possible damage. The court rejected this position and found, rather, that the Tuleys had embarked on "a responsible exercise of land management" and that they were seeking to make the different access activities "compatible inter se" in a manner consistent with and "in furtherance of their principal duty in section 3(1) of the Act". 49

An important part of the decision in Tuley is its recognition of a link between a landowner's purpose in doing something in the legitimate use or development of the land and the "scheme of the Act" ${ }^{50}$ factor of responsible exercise. Noting the subjective nature of the notion of "purpose" the Court first observes that

the scheme of the Act, and its reliance on the very protean concepts of acting "responsibly" if anything endorses that subjective approach, which ultimately may focus on the bona fides of the landowner. ${ }^{51}$

The opinion goes on to note that

in the context of section 14(1) of the Act, it envisages many agricultural activities which may have the foreseeable result of preventing responsible access but which is done for the wider purpose of the agricultural management of the land. ${ }^{52}$

This linking is of obvious importance in its recognition that the landowner's legitimate use of the land concerned will be relevant to the decision whether or not an access taker's conduct is a "responsible exercise".

The crop spraying example given in the previous section ${ }^{53}$ is an illustration of an "agricultural or other operation on the land" providing a legitimate basis for the suspension of access because it would clearly not be an operation carried out "for

49 Graham and Margo Tuley v Highland Council 2009 SLT 616 para 35.

50 Graham and Margo Tuley v Highland Council 2009 SLT 616 para 41.

51 Graham and Margo Tuley v Highland Council 2009 SLT 616 para 41.

52 Graham and Margo Tuley v Highland Council 2009 SLT 616 para 41.

53 See above n 42: 
the purpose or for the main purpose of preventing or deterring" otherwise legitimate access. $^{54}$

\section{$4 \quad$ Excluded land}

The enacted provision excludes land on general and particular bases. The limited scope of general exclusions focuses on protecting working installation interests and domestic home privacy while the specific exclusions are reflected in a listing of particular categories of land in respect of which the provision of access would be inappropriate. The general limits are more important because they go to defining the right's core character and, of course, the extent to which it diminishes the right of ownership. In the structure of the Act, section 6 lists the categories of land excluded by reason of existing use or designation and section 7 supplements and qualifies the list. The end result is complex and only an overview can be given here.

This 'type of land' limitation is distinguishable from a denial of access on the basis of conduct already discussed. Malcolm Combe ${ }^{55}$ noted this important difference in an instructive comment:

... there are two types of case in which a purported access taker may not be entitled to take access: first, with reference to the land in question (a 'where' case), and secondly, with reference to that individual's conduct (a 'how' case)."

This section will focus on the domestic home privacy exclusion which, perhaps unsurprisingly, has been central in some contentious litigation. But, first, the exclusions on various particular bases will be briefly mentioned.

The Act excludes from the right of public access land associated with some form of works installation "to the extent that there is on it...a building, or other structure ${ }^{56}$ or works, plant or fixed machinery"57 and the land forms, either, the "curtilage ${ }^{58}$ of a

54 Section 14(1)(d) Land Reform (Scotland) Act 2003.

55 Combe 2008 Edin L R 463, 464.

56 Section 6(2) Land Reform (Scotland) Act 2003 provides that for the purposes of this provision "a bridge, tunnel, causeway, launching site, groyne, weir, boulder weir, embankment of a canalised waterway, fence, wall or anything designed to facilitate passage is not to be regarded as a structure".

57 Section 6(1)(a)(i) Land Reform (Scotland) Act 2003. 
building which is not a house or of a group of buildings none of which is a house"59 or "forms a compound or other enclosure containing any such structure, works plant or fixed machinery". 60

School land is also excluded by association with a building (obviously, in this case, a school building) insofar as it "consists of land contiguous to and used for the purposes of a school". ${ }^{61}$

The legislation excludes land used for various purposes seen to be incompatible with a right of public access. The following are excluded:

Sports and playing fields in use (but golf greens, bowling greens, cricket squares and lawn tennis courts are excluded absolutely) and land developed for recreational purposes if access would interfere with the recreational use; fields of sown or growing crops; building, engineering, demolition, mining, quarry and statutory undertaking sites (e.g. Scottish Water); airport and railway land; land in respect of which access is curtailed under any other enactment to the extent of the limitation; shared private residents' gardens (as in Edinburgh New Town) and land in respect of which an entry fee was payable prior to 31 January 2001 and continues to be payable on at least 90 days in the year. ${ }^{62}$

\subsection{Privacy - the flashpoint}

A significant issue for the draftsman of a general public right of access to private land was of course the privacy of persons residing on the land. This had necessarily to be a primary consideration concerning the extent of the inroad into the right of ownership. Any general right of access to private land - regardless of qualifications

58 I.e. the particular associated area.

59 Section 6(1)(b)(i) Land Reform (Scotland) Act 2003.

60 Section 6(1)(b)(ii) Land Reform (Scotland) Act 2003.

61 Section 6(1)(b)(iii) Land Reform (Scotland) Act 2003. A school is defined in s 7(4) as not only one within the meaning of $S$ 135(1) of the Education (Scotland) Act 1980 but also "any other institution which provides education for children below school age within the meaning of that provision".

62 For details of the particular exclusions see the provisions of ss 6 and 7 Land Reform (Scotland) Act 2003. 
as to purpose - without sufficient specific protection of domestic privacy would have been unacceptable.

The domestic privacy exclusion applicable to land on which there is a house or "a caravan, tent or other place affording a person privacy or shelter"63 requires "sufficient adjacent land to enable persons living there to have reasonable measures of privacy in that house or place to ensure that their enjoyment of that house or place is not unreasonably disturbed". ${ }^{64}$

Some clarification of the intended meaning of this provision is provided in the supplementary provision requiring that "the location and other characteristics of the house or other place" be included "among the factors which go to determine what extent of land is sufficient for the purposes mentioned in s 6(1)(b)(iv)". ${ }^{65}$

The first decision on the critical issue of the scope of the right of access in terms of a tension with the privacy of a landowner's domestic sphere was in Gloag $\vee$ Perth \& Kinross Council and the Ramblers' Association. ${ }^{66}$ This matter, decided by Sheriff Michael J Fletcher, was concerned with Kinfauns Castle near Perth, the residence of bus and coach tycoon Ann Gloag. In issue was access to 4.45 hectares of land, the enclosed grounds of a mansion house with a floor area of some 4,800 square metres - almost 0.5 of a hectare.

An important part of Sheriff Fletcher's opinion dealt with the interpretation of the exclusion of access on the basis of privacy. In response to a submission on behalf of the Ramblers Association that the issue was whether exclusion of the public to the limit of the fence was necessary for the enjoyment of the house, the learned Sheriff pointed out that the wording did not support a construction involving "necessity to show that exclusion is required". ${ }^{67}$ Rather, "the landowner is entitled to sufficient land to be excluded to ensure (my emphasis) ${ }^{68}$ that their enjoyment of the house is not

63 Section 6(1)(a)(ii) Land Reform (Scotland) Act 2003.

64 Section 6(1)(b)(iv) Land Reform (Scotland) Act 2003.

65 Section 7(5) Land Reform (Scotland) Act 2003.

66 Gloag v Perth \& Kinross Council and the Ramblers' Association 2007 SCLR 530.

67 Gloag v Perth \& Kinross Council and the Ramblers' Association 2007 SCLR 530 para 42.

68 i.e. Sheriff's emphasis. 
unreasonably disturbed". ${ }^{69}$ The legislation in fact says "that house or place" and so envisages possible differentiation depending upon the type of property involved. But nothing other than a variable measure dependent upon the circumstances could be apposite to the determination of the meaning of "reasonable measures of privacy in that house or place" sufficient "to ensure that their enjoyment of that house or place is not unreasonably disturbed". ${ }^{70}$ In the scheme of the Act, land within the zone of the privacy exclusion is land over which access rights are not exercisable. This is made clear in section 1 establishing the right - "land in respect of which access rights are exercisable is all land except that specified in or under section 6 below". ${ }^{71}$ It is submitted that this construction means that a landowner can assert a certain sphere of domestic privacy and deny entry into that sphere to persons seeking access who, in turn, may challenge the position on the basis that it does not meet the relevant privacy criterion. It should also be noted that certain distinguished academic commentators appear not to subscribe to the interpretation of a sphere of privacy depending on the nature and circumstances of the property. John Lovett says that "[t]he LRSA does not grant large landowners an entitlement to greater amounts of privacy and personal autonomy than owners of more modest estates". ${ }^{72}$ While any introduction of a notion of "genuine access taker" ${ }^{73}$ not provided for in the legislation seems unworkable, ${ }^{74}$ a compelling point in the discussion part of Sheriff Fletcher's opinion is the observation that the specific exclusion of shared private gardens ${ }^{75}$ seems consistent with legislative policy to exclude "garden areas round private houses". ${ }^{76}$

Applying an objective "reasonableness" test to determine the area of ground sufficient for the privacy of residents ${ }^{77}$ the court considered it "certain...that a reasonably substantial area of ground standing the nature of the property is excluded

69 Gloag v Perth \& Kinross Council and the Ramblers' Association 2007 SCLR 530 para 42.

70 Section 6(1)(b)(iv) Land Reform (Scotland) Act 2003.

71 Section 1(7) Land Reform (Scotland) Act 2003.

72 Lovett $2010 \mathrm{Neb} L \operatorname{Rev} 796$. See also Reid and Gretton Conveyancing 131-132, where the learned authors comment on the issue of "large gardens for large houses in Gloag".

73 Arising from the expert evidence of an access officer in Gloag (para 18) but not taken forward in the Sheriff's decision.

74 See Combe 2008 Edin L R 467; Lovett 2010 Neb L Rev 794.

75 Section 6(1)(c) Land Reform (Scotland) Act 2003.

76 Gloag v Perth \& Kinross Council and the Ramblers' Association 2007 SCLR 530 para 49.

77 Gloag v Perth \& Kinross Council and the Ramblers' Association 2007 SCLR 530 para 52. 
from access rights by the terms of section $6 " .{ }^{78}$ On this basis it was decided that, while enjoyment of the house depended upon a number of factors, "it could not be ensured by a smaller area [than the circa 4.5 hectares $^{79}$ ] of adjacent ground...taking into account the location and characteristics of the house". 80

Shortly after the Gloag decision, Snowie v Stirling Council and the Ramblers' Association $^{81}$ was decided by Sheriff A M Cubie. This case involved Boquhan House and other dwellings, all part of a 28 hectare property near Stirling. The court rejected a submission that the privacy factor was properly determined by reference to "the standards of the persons affected in the house i.e. that the test was "person specific" and "location specific". ${ }^{82}$ Agreeing with the approach in Gloag, the court applied an objective test in deciding that while the entire property was not excluded "a reasonably substantial area of ground" needed to be excluded to "ensure that enjoyment of the house was not unreasonably disturbed". 83 The court made the important point that the purpose of excluding certain ground was "not to secure the enjoyment of the 'policies' for the occupants of the house, but to secure the enjoyment of the house itself". ${ }^{84}$ The end result was an order excluding an area of about 5 hectares around the mansion house. This outcome is broadly consistent with that in Gloag but the results are distinguishable in that the Snowies were seeking an exclusion extending to their entire 28 hectare estate.

An aspect of Snowie distinguishing it from Gloag was the existence of a common law right of way. While statutory access rights are not affected by the existence of a transversing right of way, ${ }^{85}$ arguably Sheriff Cubie was correct in expecting to be informed as to the right of way. ${ }^{86} \mathrm{~A}$ right of way could have implications for the privacy issue in identifying a prevailing access position, unchallengeable by the landowner. But in principle the existence of a right of way route should not come into

78 Gloag v Perth \& Kinross Council and the Ramblers' Association 2007 SCLR 530 para 59.

79 Author's note.

80 Gloag v Perth \& Kinross Council and the Ramblers' Association 2007 SCLR 530 para 60.

81 Snowie $v$ Stirling Council and the Ramblers' Association 2008 SLT (Sh Ct) 61.

82 Snowie $v$ Stirling Council and the Ramblers' Association 2008 SLT (Sh Ct) 61 para 51.

83 Snowie $v$ Stirling Council and the Ramblers' Association 2008 SLT (Sh Ct) 61 para 56. It may be noted that Sheriff Cubie in para 48 adopts "verbatim the analysis of the law contained in Sheriff Fletcher's judgement in Gloag" [paras 24-31].

84 Snowie $v$ Stirling Council and the Ramblers' Association 2008 SLT (Sh Ct) 61 para 56.

85 Combe 2008 Edin $L R$ 466-467.

86 Snowie $v$ Stirling Council and the Ramblers' Association 2008 SLT (Sh Ct) 61 para 36. 
the reckoning in a question of whether or not the landowner's right under section 6(1)(b)(iv) defeated a claim to access in fact more intrusive of privacy than that produced by the right of way.

Ross v Stirling Council ${ }^{87}$ was a companion decision to Snowie. Professor and Dr Ross owned and resided in the West Lodge, a detached house with garden ground within the Boquhan Estate. While the two cases were as one in terms of common opposition to access over the estate they were different in their respective claims to section 6(1)(b)(iv). Sheriff Cubie recognised this.

Again, I agree with Sheriff Fletcher in that anyone contemplating the purchase of a house such as Kinfauns Castle or Boquhan House would not consider doing so if the house itself and its grounds (and by that I mean a material area around the house) were not able to be used by them privately. The West Lodge, while in a very scenic location is not in the same category of property, and accordingly will give rise to different considerations about what constitutes sufficient ground. ${ }^{88}$

Creelman v Argyll and Bute Council 2009, ${ }^{89}$ decided by Sheriff Derek Livingston, involved a 2.4 hectare property on which two houses stand, the five bedroomed Stronardron House and the smaller Dunans Lodge. About one third of the total property area is precipitous and inaccessible. Mr and Mrs Creelman, who lived in the bigger house and let out the smaller one, demonstrated their commitment to the long-term project of developing the entire accessible property as a garden. The public access issue was initiated by neighbouring landowner, Mr Dickson Spain, who wanted, as part of a commercial venture, to bring visitors to his Dunans Castle via pedestrian access through the Creelmans' land made possible only by the Creelmans' work. The local authority, supporting the idea, took the matter up under section 14 of the Act - allowing a local authority to challenge action by a landowner denying access - when the Creelmans put up a "no access" sign. Taking into account a wide range of particular considerations, the court found that only a total exclusion of access rights would allow "reasonable privacy within what might be said to be their reasonable garden area". ${ }^{90}$ In arriving at this conclusion the court paid attention to section $7(5)$ pointing to "the location and other characteristics of the

87 Lindsay and Barbara Ross v Stirling Council 2008 SLT (Sh Ct) 61.

88 Lindsay and Barbara Ross $v$ Stirling Council 2008 SLT (Sh Ct) 61 para 56.

89 Creelman v Argyll and Bute Council 2009 SLT (Sh Ct) 165.

90 Creelman v Argyll and Bute Council 2009 SLT (Sh Ct) 165 para 66. 
house" as factors relevant to "what extent of land is sufficient" for the purposes of a determination on the privacy exclusion under section 6(1)(b)(iv). Relevant in this regard was evidence "that the land here was small for a house the size of Stronardron in that type of locality". ${ }^{91}$

The decision in Forbes $v$ Fife Councip ${ }^{22}$ is distinguishable from the privacy exclusion issue cases of Gloag, Snowie and Creelman concerned with the position of large rural houses and the delineation of a sufficient private sphere. The matter, however, does have a certain similarity to Ross in that both involved the issue of possible exclusion of access beyond their boundaries on the basis of the privacy associated with a dwelling house.

In Forbes the issue was not access to garden ground but to an adjacent path, held by the pursuers in common with six neighbouring landowners. The fundamental question was if the use of the path by the public was precluded on the basis of the section 6(1)(b)(iv). Findings of fact that the pursuers' house was situated away from a six-foot fence which separated their reasonably sized garden from the path made it difficult to make a case for a sphere of privacy extending beyond their garden ground. Giving the pursuers' case every consideration the court took the view that "what is happening on the land is a factor to which regard may be had, along with all the other factors, before reaching a decision as to what is sufficient adjacent land". ${ }^{93}$ Accordingly, in the example of a house in the middle of a field, evidence that access is regularly taken by passing very close to the house "may be relevant in helping to set the bounds of what is sufficient adjacent land". 94 The introduction of this potential variable $^{95}$ does not fit an otherwise objective assessment of circumstances. Those who venture closer than an objectively determined limit do not have an access right and are vulnerable to the landowner's common law rights.

91 Creelman v Argyll and Bute Council 2009 SLT (Sh Ct) 165 para 67.

92 Forbes $v$ The Fife Council 2009 SLT (Sh Ct) 71.

93 Forbes $v$ The Fife Council 2009 SLT (Sh Ct) 71 para 28.

94 Forbes $v$ The Fife Council 2009 SLT (Sh Ct) 804 para 28.

95 Lovett $2010 \mathrm{Neb}$ L Rev 71. 


\section{$5 \quad$ Scottish Outdoor Access Code}

A part of the access rights package under Part 1 of the Act is the provision in Chapter 3 for a code to be produced by Scottish Natural Heritage. The Act provides, first, that the Code should set out - in relation to access rights - guidance as to the circumstances in which "those exercising these rights are to be regarded as doing so in a way which is or is not responsible". ${ }^{96}$

Section 10 goes on to provide that the Code should also give guidance, on conduct by third parties - i.e. neither access-takers nor landowners - likely to affect the exercise of access rights; the use, management or other conduct by landowners in a way which is or is not responsible; and the use, management or other conduct by landowners in respect of which rights are not exercisable but are likely to affect the exercise of those rights on contiguous land. ${ }^{97}$

Published in 2005 the Code contains much useful detail but its "user friendly" composition does not always lend itself to interpretation of the Act. For example, the Act in section 2(1) says that "a person has access rights only if they are exercised responsibly"; the relevant part of the Code starts with the statement "[y]ou must exercise access rights responsibly", which is less strong than the formulation of the Act in that it fails to present the plain position that the right is only one of responsible exercise.

Sheriff Fletcher in the Gloag case did not find the Code of assistance: "looking at the terms of the Code it is clear that it is prepared as a practical guide...rather than an aid to interpretation". ${ }^{98}$ Regarding the interpretation of section 6 , on the important issue of the privacy of the resident of a dwelling, he took the view that "it cannot be said that the advice and guidance given by the Code is a direct help to the interpretation of section 6". 99

96 Section 10(1)(a) Land Reform (Scotland) Act 2003.

97 Section 10(1)(b), (c) and (d) Land Reform (Scotland) Act 2003.

98 Gloag v Perth \& Kinross Council and the Ramblers' Association 2007 SCLR 530 para 35.

99 Gloag v Perth \& Kinross Council and the Ramblers' Association 2007 SCLR 530 para 36. 
But while the Code probably has limited utility as an aid to the interpretation of the statutory provisions, it may be of use in terms of guidance on particular issues. Sheriff Fletcher in the Gloag case, dealing with the point that access rights "are available only if they are exercised responsibly", observed that a party engaging in conduct specifically excluded by section 9 "would not be exercising access rights responsibly" and went on to note that "[s]imilarly disregarding the guidance on responsible conduct set out in the Access Code incumbent upon persons exercising access rights would not be exercising access rights responsibly". ${ }^{100}$ This reflects the wording of section 2(2)(b) of the Act. The Code therefore has a potentially significant role to play in the comprehensive range of particular matters of "responsible behaviour" by the public and by land managers provided for in Part 5.

\section{The European Convention on Human Rights}

Both the general protection of the right of property under Protocol 1, Article 1 and the particular protection of a person's rights in respect of private and family life and the home under Article 8 are potentially relevant to the question of whether or not the radical Scottish provision for public access to private land complies with the European Convention on Human Rights (ECHR).

Protocol 1 Art.1 provides:

(1) Every natural or legal person is entitled to the peaceful enjoyment of his possessions. No one shall be deprived of his possessions except in the public interest and subject to the conditions provided for by law and by the general principles of international law.

(2) The preceding provisions shall not, however, in any way impair the right of a state to enforce such laws as it deems necessary to control the use of property in accordance with the general interest or to secure the payment of taxes or other contributions or penalties.

The obvious latitude, especially in respect of land, for limitations in the public or general interest is confirmed in the relevant jurisprudence. ${ }^{101}$ The recognition of a tension in the terms of the grundnorm provision itself has, of course, led to a

100 Gloag v Perth \& Kinross Council and the Ramblers' Association 2007 SCLR 530 para 25; this dictum is part of Sheriff Fletcher's opinion adopted by Sheriff Cubie in Snowie $v$ Stirling Council and the Ramblers' Association 2008 SLT (Sh Ct) 61 para 48 (see above n 83).

101 See, for example, James $v$ UK 19868 EHRR 116. 
jurisprudence emphasising the necessity of a balancing-of-interests approach without obvious challenge to the position of states to control landownership in accordance with national priorities. In terms of the substance of norms controlling the constituent rights which make up land ownership, one might say that the lex situs notion prevails. Consistent with this thinking, and importantly in the present context, the case law has come to recognise that the detail of a controlling requirement of balancing is appropriately dealt with in the statute. The Scottish access legislation does this and, to this extent, is probably proof against constitutional challenge. It is submitted that the comments of Professor André van der Walt relating to the English access provision apply equally to the Scottish legislation.

The 2000 English Act $^{102}$ defines public access to access land fairly widely but imposes strict limits on it. Because the Act explicitly establishes a fair balance between public access rights and the private rights of the landowners it could effectively and successfully deprive landowners, without providing for compensation, of their right to sue in trespass anyone who enters the land without their permission. ${ }^{103}$

Of course, at the domestic level the implications of the required legislative balancing process must be considered and given effect to in the circumstances of particular cases. On this basis it is apparent that only relatively general precedents can be established in respect of the critical privacy issue under section 6.

The question of compliance with the fairly specific mandate of Article 8 necessarily involves matters more particular than general deprivation which, at the level of interpretation in a specific context, must of course be open to variation according to circumstances. The relevant article provides that:

(1) Everyone has the right to respect for his private and family life, his home and his correspondence.

(2) There shall be no interference by a public authority with the exercise of this right except such as is in accordance with the law and is necessary in a democratic society in the interests of national security, public safety or the economic well-being

102 Referring to the Countryside and Rights of Way Act 2000; see below, part 7.

103 Van der Walt Property in the Margins 194-195. 
of the country, for the prevention of disorder or crime, for the protection of health or morals, or for the protection of the rights and freedoms of others.

In the Gloag case ${ }^{104}$ counsel for the pursuer argued that even though it was accepted that the access provisions of the Act complied with the ECHR, Article 8 remained relevant to the decision in terms of section 6 (1)(b)(iv) of the Act as to the extent of the land around the residence over which access rights should not be exercised. The point here was that Article 8 in effect mandated an interpretation of section 6 which took account of the personal circumstances of residents of the dwelling. ${ }^{105}$

It is submitted that the role of Article 8 is not denied in Sheriff Fletcher's observations as to the interplay between the grundnorm principle and the legislative provision:

[O]nce it is accepted that the Act is not incompatible with Convention rights and assuming that the court makes a decision which was correct in relation to sufficiency [of the land excluded around a dwelling] there would be no contravention...on the other hand if the court were wrong about sufficiency that decision can be put right without reference to the Convention because it would be a contravention of the 2003 Act. $^{106}$

\section{$7 \quad$ The English law approach}

This brief overview is for the sole purpose of contrasting the general features of the English reforms, which preceded the Scottish ones by only a few years.

In English common law the act of trespass itself is actionable on the basis of the tort of trespass to land. ${ }^{107}$ The landowner's right to exclude a person present on his or her land without permission is backed up not only by a power to exclude, as in Scotland, but also by the availability of a civil action to recover damages in respect of the act of trespass.

104 Gloag v Perth \& Kinross Council and the Ramblers' Association 2007 SCLR 530.

105 Gloag v Perth \& Kinross Council and the Ramblers' Association 2007 SCLR 530 para 61.

106 Gloag v Perth \& Kinross Council and the Ramblers' Association 2007 SCLR 530 para 65.

107 See Halsbury et al Halsbury's Law of England Vol 45(2) para 505: "Every unlawful entry by one person on land in the possession of another is a trespass for which a claim may be brought, even though no actual damage is done". 
Selective limitation of a landowner's right against recreational access takers has occurred in modern times in response to a not insignificant public call for "a right to roam". The culmination of this trend came in the legislation identified in the leading general text on English land law as "[a] statutory 'right to roam"'108. The reforms provide a general right of pedestrian access to "open country". ${ }^{109}$ Only certain land is subject to the statutory "right to roam". ${ }^{110}$

Gray and Gray ${ }^{111}$ contrast the more extensive Scottish right:

The Countryside and Rights of Way Act 2000, although revolutionary in its way, still suffers from limitations which are exposed by comparison with the extensive access provision made by the Land Reform (Scotland) Act 2003. Under this enactment...every citizen has a presumptive entitlement, not to defined "access land" but to all land in Scotland subject only to express exclusions. The statutory "access rights" include the right to cross land and to use land for recreational, educational and certain commercial purposes. The range of permissible forms of access is also much less restrictive than in England, including access by foot, horse or cycle, camping, canoeing and air sports. The Scottish legislation may well provide a model for adoption or adaption in the next phase of English access legislation, not least in the light of its emphasis on the educational aspect of recreational access to the outdoors.

\section{$8 \quad$ Remedies}

The Act provides for the determination, on summary application to a sheriff court, of the central controlling issues of excluded land, responsible exercise by the access taker, and responsible management by the landowner. ${ }^{112}$ There is also provision for a determination as to the right to the crossing of land by a path, bridleway or other means, and whether on foot, horseback, pedal cycle or any combination of these means. ${ }^{113}$

108 Gray and Gray Elements of Land Law PARA 5.46.

109 Countryside and Rights of Way Act 2000 s 1(2).

110 Amounting to some $10 \%$ of the total land area of England and Wales made up of: $i /$ all land over $600 \mathrm{~m}$ above sea level (the highest mountain in England being Scafell Pike at 978m and in Wales Snowdon at $1085 \mathrm{~m}$ ) together with definitively mapped areas of "open country"; ii/ all registered common land - an extension of the "village green" idea provided for by the Commons Registration Act 1965 (c.3\% England, 9\% Wales of total land); iii/ land irrevocably dedicated by the owner for public access; see Gray and Gray Elements of Land Law paras 5.40 and 5.47.

111 Gray and Gray Elements of Land Law para 5.50.

112 Section 28(1) Land Reform (Scotland) Act 2003.

113 Section 28(2) Land Reform (Scotland) Act 2003. 
As urged above, ${ }^{114}$ the better view is that the landowner's remedy has not changed to the extent that he or she may not apply reasonable means to obtain the removal of a party who has no right under the Act. In principle, resort to interdict also remains competent. Prior to the legislation the landowner could, in principle, always obtain the removal of a party present on a precarious basis. The position has changed to the extent that in a wide range of circumstances the access taker is present on the basis of a right, but if the right is forfeited because it is not exercised responsibly, it must necessarily be that the common law remedies are available to the landowner. The party seeking access can, of course, seek a declaration from the sheriff court that his or her exercise is in accordance with the legislation.

The Act's provision for the judicial determination of issues does not displace the landowner's common law right. As a matter of principle, where the access taker has no right, as in the situation identified in the Tuley case, ${ }^{115}$ the landowner must necessarily have the right to exclude the party concerned. From a policy point of view certain obvious forms of irresponsible conduct to the potential detriment to the landowner's interests justify this residual right.

\section{$9 \quad$ Concluding observations}

Would it be accurate to say that, at any rate in broad terms, a technically precarious but de facto largely secure position has been recast on a structured correlative right/responsibility basis? For hill walkers one could hardly contend that the practical position has changed in any major way. On this basis, while the Scottish access to land reforms are from one perspective radical they may also be seen as simply making the longstanding de facto position of public access to the hills and mountains a de jure situation. But, as will be noted shortly, this is only part of the picture.

An aspect of the shift - perhaps insufficiently recognised - is the proximity between the former de facto position and the reformed regime, because of the critical factor of a right contingent upon responsible exercise. As already stated, the only Court of

114 See 3.1 prerequisite condition of responsible exercise.

115 Graham and Margo Tuley v Highland Council 2009 SLT 616. For an analysis of the decision see Combe 2010 Edin L R 106, 107-109. 
Session decision relevant to the issue has confirmed that the right is denied if its exercise is not responsible. ${ }^{116}$ Arguably, the movement has been from a precarious position to a right revocable on the basis of irresponsible exercise - significantly, a qualified legal right. ${ }^{117}$ The "responsible exercise" factor leaves the landowner in a position to assert his property interest albeit no longer on an arbitrary basis but only in circumstances in which it is under actual threat. Another relevant difference here is that the access taker's thinking now is that in principle he or she has the right to proceed.

But this characterisation is an oversimplification in a number of ways. Previously not well known in Scotland, "ramblers" have joined the hill walkers; the reforms have added a dimension and opened up potential access to land in general including much more than the extensive - and largely wilderness - hill and mountain areas of Scotland. Of course the "all land" aspect of the reforms multiplies the extent to which there may be a "responsible access" issue, because the likelihood of conflict between the access taker and the landowner is much greater in the context of developed land.

From the comparative law perspective of the conference at which this paper, in its initial form, was given, one can only say that the Scottish reforms reflect the trite point that the lex situs factor remains predominant in land law. Subscription to the ECHR supra-jurisdiction norm has implications for the form of any redistribution of rights - more or less as a matter of fair process - but the substance remains essentially a matter for domestic law.

The South African Constitution sets out a controlling agenda for land reform with major implications for the protection of property in terms of the position of the common law. As part of that development the landowner's power to evict has been redefined but without recognition of any general notion of public access to private property. However, as Professor André van der Walt has shown, post-apartheid case

116 Graham and Margo Tuley v Highland Council 2009 SLT 616.

117 See Lovett $2010 \mathrm{Neb}$ L Rev 742 contrasting the "right to exclude" regime with a position favouring responsible access under the Act: "the [Act] actually replaces the traditionally robust, modular, ex ante presumption in favor of the right to exclude with a surprisingly simple, but also robust, ex ante presumption in favor of responsible access..." 
law does reflect certain moves to restrict a landowner's general right to exclude. ${ }^{118}$ But a limit on the power to exclude persons, on the basis of their behaviour, from private premises open to the public ${ }^{119}$ is different in kind from a general right of public access for recreational and educational purposes. 


\section{Bibliography}

Combe 2008 Edin $L R$

Combe MM "No Place Like Home: Access Rights over 'Gardens'" 2008 Edin L $R$ 463-468

Combe 2010 Edin L R

Combe MM "Access to Land and to Landownership" 2010 Edin L R 106-113

Gray and Gray Elements of Land Law

Gray K and Gray SF Elements of Land Law $4^{\text {th }}$ ed (Oxford University Press Oxford 2005)

Guthrie "Access Rights"

Guthrie T "Access Rights" in Rennie R (ed) The Promised Land: Property Law Reform (Thomson/Green Edinburgh 2008)

Halsbury et al Halsbury's Laws of England

Halsbury HSG et al Halsbury's Laws of England - Vol 45(2) $4^{\text {th }}$ ed (Butterworths London 1993)

Lovett 2010 Neb L Rev

Lovett JA "Progressive Property in Action: The Land Reform (Scotland) Act 2003" 2010 Neb L Rev 739-818

Norrie "Intentional Delicts"

Norrie K "The Intentional Delicts" in Reid KGC and Zimmermann R (eds) $A$ History of Private Law in Scotland - Volume II: Obligations (Oxford University Press Oxford 2000)

Paisley Access Rights

Paisley RRM Access Rights and Rights of Way: A Guide to the Law in Scotland (Scottish Rights of Way and Access Society Edinburgh 2006) 
Reid Law of Property

Reid KGC The Law of Property in Scotland (Law Society of Scotland/Butterworths Edinburgh 1996)

Reid and Gretton Conveyancing

Reid KGC and Gretton GL Conveyancing 2007 (Avizandium Edinburgh 2008)

Rowan-Robertson and Ross 1998 Edin L $R$

Rowan-Robertson $\mathrm{J}$ and Ross $\mathrm{A}$ "The Freedom to Roam and Implied Permission" 1998 Edin L R 225-233

Scottish National Heritage Access to the Countryside

Scottish National Heritage Access to the Countryside for Open-air Recreation: Scottish Natural Heritage's Advice to Government (Scottish National Heritage Redgorton 1998)

Sellar 2006 Norwegian Journal of Geography

Sellar DH "Scotland: The Great Land Debate and the Land Reform Act" 2006 Norwegian Journal of Geography 100-109

Shoard Right to Roam

Shoard M A Right to Roam (Oxford University Press Oxford 1999)

Smith British Justice

Smith TB British Justice: The Scottish Contribution (Stevens \& Sons London 1961)

Smith Short Commentary

Smith TB A Short Commentary on the Law of Scotland (Green Edinburgh 1962)

Van der Walt Property in the Margins

Van der Walt A Property in the Margins (Hart Oxford 2009) 


\section{Register of case law}

Creelman v Argyll and Bute Council 2009 SLT (Sh Ct) 165

Dumbreck v Addie 1928 SC 547

Forbes $v$ The Fife Council 2009 SLT (Sh Ct) 71

Gloag v Perth \& Kinross Council and the Ramblers' Association 2007 SCLR 530

Graham and Margo Tuley v Highland Council 2009 SLT 616

Highland Council v Graham and Margo Tuley 2007 SLT (Sh Ct) 77

James $v$ UK 19868 EHRR 116

Jenkins v Murray 1866 4M 1046

Lindsay and Barbara Ross v Stirling Council 2008 SLT (Sh Ct) 61

Snowie v Stirling Council and the Ramblers' Association 2008 SLT (Sh Ct) 61

Victoria \& Albert Waterfront (Pty) Ltd v Police Commissioner, Western Cape 20044 SA $444(\mathrm{C})$

Wood v North British Railway 1899 2F 1

\section{Register of legislation}

Commons Registration Act 1965

Countryside and Rights of Way Act 2000

Criminal Justice and Public Order Act 1994

Education (Scotland) Act 1980

Land Reform (Scotland) Act 2003

Trespass (Scotland) Act 1865

Wildlife and Natural Environment (Scotland) Act 2011

\section{Register of internet sources}

Anon [Date unknown] www.snh.gov.uk

Anon [Date unknown] Scottish Outdoor Access Code www.snh.gov.uk/docs/A309336.pdf [date of use 15 June 2012]

Cairngorm Club [Date unknown] www.cairngormclub.org.uk 
Cairngorm Club [Date unknown] The Cairngorm Club www.cairngormclub.org.uk [date of use 15 June 2012]

Carey Miller and Combe 2006 www.ejcl.org

Carey Miller DL and Combe MM 2006 "The Boundaries of Property Rights in Scots Law" 2006 Electronic Journal of Comparative Law www.ejcl.org/103/art103-4.pdf [date of use 15 June 2012]

National Access Forum [Date unknown] www.outdooraccess-scotland.com National Access Forum [Date unknown] Scottish Outdoor Access Code www.outdooraccess-scotland.com/access-forum/history-and-achievements/ [date of use 15 June 2012]

\section{List of abbreviations}

ECHR European Convention on Human Rights

Edin L R Edinburgh Law Review

Neb L Rev Nebraska Law Review 